\title{
The effects of traditional fermented beverages on ethanol, ethyl glucuronide and ethyl sulphate levels
}

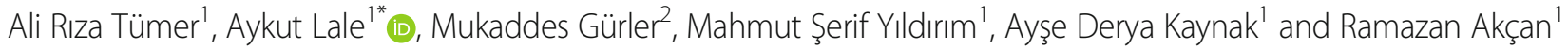

\begin{abstract}
Background: Traditional beverages such as şalgam, boza, kımız and kefir are frequently being consumed in Turkey. During the production of these beverages fermentation provides long time bio-preservation due to protective effects of ethanol, a product of microorganisms' metabolism. Especially in traffic controls and in rehabilitation process of alcoholic patients, fermented beverages may cause confusion since it may be linked with false positivity of ethanol and ethanol metabolite tests. The present study aims to assess blood ethanol and urine ethanol metabolite levels after consumption of traditional fermented beverages.

Method: Twelve participants consumed $300 \mathrm{~mL}$ standardized homemade traditional şalgam, boza, kımız and kefir. Blood samples were collected before and after (at $45^{\text {th }} \mathrm{min}$ ) consumption and urine samples were collected before and after (at $4^{\text {th }}$ hour) consumption from the participants. The samples of these four beverages and the blood samples were analyzed using headspace gas chromatography for ethanol levels, and urine samples were analyzed with liquid chromatography tandem mass spectrometry for ethyl-glucuronide and ethyl-sulphate levels.

Results: Ethanol levels in şalgam, boza, kımız, and kefir samples, used at the present study, were $80.02 \mathrm{mg} / \mathrm{dl}, 30.02 \mathrm{mg} /$ $\mathrm{dl}, 57.83 \mathrm{mg} / \mathrm{dl}$ and $6.07 \mathrm{mg} / \mathrm{dl}$, respectively. After consumption of beverages, blood ethanol levels were negative for all analyzed samples. No statistically significant correlation was found between initial and post-consumption ethyl-glucuronide and ethyl-sulphate levels.
\end{abstract}

Keywords: Blood alcohol levels, Urinary ethylglucuronide, Urinary ethylsulphate, Fermented beverages, Ethanol

\section{Background}

Traditional beverages produced by fermentation and are being consumed frequently all over the world. Fermentation, the oldest and economical method, provides long time bio-preservation secondary to microorganism metabolism (Tamang and Kailasapathy 2010). Şalgam, Boza, Kımı, and Kefir are mostly known and frequently consumed fermented beverages in Turkey.

Şalgam is a purplish red colored, cloudy and sour soft beverage which is produced using some fermentation steps of a mixture of turnips, black carrot, bulgur (broken wheat) , flour, salt, and water (Altay et al. 2013; Kabak and Dobson 2011). A similar product known as Kanji is produced in India (Rati Rao et al. 2006). Boza has a pale yellow color,

\footnotetext{
*Correspondence: aykutlale@gmail.com

${ }^{1}$ Department of Forensic Medicine, Hacettepe University Medical Faculty,

06100 Ankara, Turkey

Full list of author information is available at the end of the article
}

viscous consistency and sweet or sour taste. It is produced from millet, maize, wheat, or rice semolina or flour by yeast and lactic acid fermentation. Boza is widely consumed in Turkey, Bulgaria, and some other countries of the Balkan generally in winter months. Kefir has a viscous, smooth, slightly foamy consistency and a whitish color. It is a fermentation product of milk using kefir grains. Kımız also known as koumiss, airag, kumys, or kumis, is a beverage made from mares' milk with milky-grey color and acidic taste. It is consumed in Turkey, Mongolia, Kazakhstan, Kyrgyzstan, and in some regions of Russia (Altay et al. 2013; Kabak and Dobson 2011).

Ethyl-glucuronide (EtG) is one of non-oxidative minor metabolites of ethanol that catalyzed by UDPglucuronosyltransferase. Glucuronidation of ethanol was firstly described by Neubauer in 1901, and EtG was firstly analyzed by Kamil et al. (Wurst et al. 2000). Similarly, ethyl-sulphate (EtS) is composed of conjugating a 
sulfate group to ethanol by sulfotransferase enzyme (Helander and Beck 2004). Studies have shown that very few concentration of ethanol ( \% 0.1) is excreted in urine by turning into EtG and EtS. Additionally these minor metabolites gain an advantage to determine recent intake of ethanol, since they remain detectable longer time than ethanol in blood and urine (Walsham and Sherwood 2014). Using cutoff levels with the best balanced sensitivity and specificity recent consumption amount and/or time of ethanol could be determined for forensic purposes and substance abuse treatment (SAMHSA - Substance Abuse and Mental Health Services Administration 2012). Also it could be possible to distinguish incidental ethanol exposure from real cases (Walsham and Sherwood 2014).

Ethanol is an end product of the fermentation and is found in non-alcoholic fermented beverages at small amounts (Magalhães et al. 2011; Uysal et al. 2014). This traditional information is known by local residents and sometimes it is used as a claim at traffic controls which are resulted with positive breath alcohol test. The present study is aimed to investigate the effects of frequently consumed fermented beverages Şalgam, Boza, Kımız, and Kefir on blood alcohol level and urine alcohol metabolites.

\section{Materials and methods}

\section{Supplying of beverages}

Şalgam, boza, and kımız which were commercially manufactured by traditional method were supplied just before the application of experimental procedure. Kefir was produced using pasteurized cow milk with traditional method. Kefir grains, purchased from Sales Office of Agriculture Faculty of Ankara University, were directly added to the pasteurized and cooled milk, then incubated for $24 \mathrm{~h}$ at $25{ }^{\circ} \mathrm{C}$. After fermentation, kefir was obtained by separating the grains from the beverage. Samples from these four fermented beverages were collected for testing their alcohol contents.

\section{Participants}

A total of 12 healthy volunteers, five women and seven men, were included in the study. They had an alcoholfree diet without any fermented food or beverage for the last 3 days before study for each beverage.

\section{Experimental procedure}

The experimental procedure was approved by the Hacettepe University Ethical Committee and all the volunteers signed an informed consent form.

Before the experimental procedure, the volunteers were asked to stay hungry for at least $8 \mathrm{~h}$. The study was performed at 8 a.m. on different days for different fermented beverages. Blood $(3 \mathrm{~mL})$ and urine $(20 \mathrm{~mL})$ samples were collected both before and after consuming $(300 \mathrm{~mL})$ of beverage. The blood samples after the consumption were obtained at $45^{\text {th }} \mathrm{min}$, and urine samples were taken at $4^{\text {th }} \mathrm{h}$ depending on pharmacokinetic properties of ethanol, EtG and EtS. When second blood samples were taken, the volunteers were allowed to have a light breakfast. This experimental procedure was repeated for all fermented beverages with a 2 weeks interval; Kımı, Şalgam, Boza, and Kefir, respectively.

\section{Sample analyses}

Blood and beverage samples were analyzed for ethanol concentrations. Urine samples were analyzed to determine EtG and EtS levels. Samples were prepared without storage after collection for analysis and the results were obtained on the same day.

\section{Instrumentation}

Blood ethanol levels were analyzed with headspace gas chromatograph (HS - GC). All GC experiments were performed using Agilent Technologies 7890B GC system coupled with a flame ionization detector (FID), equipped with Agilent J\&W HP5 dual capillary column $(30 \mathrm{~m} \times 0$. $32 \mathrm{~mm}$ i.d. $\times 0,25 \mu \mathrm{m}$ film thickness). The preconcentration step was accomplished using an Agilent 7694E Headspace Sampler.

Urine EtG and EtS levels were analyzed by using Shimadzu $8030+$ MS/MS system coupled with Nexera XR LC-20 AD liquid chromotograph, equipped with a Shim-Pack Column FC-ODS 150X2.0 by Shimadzu.

\section{Reagents and calibrators}

All chemicals used in experimental procedure were LC gradient grade. EtG and EtS standards and the internal standards (IS) EtG D5 and EtS D5 were purchased from Lipomed (Swiss Health Care Company); acetonitrile, methanol, ethanol and n-propanol from Merck and ammonium formate from Sigma Aldrich. Ultra-pure water (18.1 M $\Omega$ ) was produced by a Mes Mp Minipure water system (MPMINIPURE,Turkey).

\section{Sample preparation}

Blood and beverage samples were mixed with IS (n-propanol) at a ratio of $0.2 / 0.8$ in the head space gas chromatography vials for ethanol testing.

Urine samples were first mixed with acetonitrile $(v / \mathrm{v}=$ 1/1), then centrifuged for $5 \mathrm{~min}$ at $14000 \mathrm{rpm}$. The supernatant $(200 \mu \mathrm{L})$ was transferred to the auto sampler vial and fortified with IS EtG D5 and EtS D5 $(100 \mathrm{ng} / \mathrm{mL})$ before LC-MS/MS injection.

\section{Instrumental conditions}

The condition parameters of HS-GC are shown in Table 1. In LC-MS/MS analyses, the aqueous mobile phase (phase A) consisted of $10 \mathrm{mM}$ ammonium formate in water, while 
Table 1 Condition parameters for gas chromatographic analysis (Gas Chromotography - Flame Ionization Detector (GC-FID) procedure)

\begin{tabular}{ll}
\hline Carrier gas & Helium $20 \mathrm{~cm}^{3} \mathrm{~min}^{-1}$ \\
\hline Detector & $\mathrm{FID} ; 260{ }^{\circ} \mathrm{C}$ \\
Detector gases & Hydrogen $30 \mathrm{~cm}^{3} \mathrm{~min}^{-1}$ \\
& Air $300 \mathrm{~cm}^{3} \mathrm{~min}^{-1}$ \\
Injector & Split/splitless type; $250^{\circ} \mathrm{C}$ \\
& Split $20: 1$ \\
Temperature program & Initial temperature $40{ }^{\circ} \mathrm{C}$. ramped at $37^{\circ} \mathrm{C} \mathrm{min}$ rin $^{-1}$ \\
& to $260^{\circ} \mathrm{C}$. hold 6 min; total analysis time $24 \mathrm{~min}$ \\
\hline
\end{tabular}

the organic mobile phase (phase B) consisted of methanol. The analytical column was maintained at $40{ }^{\circ} \mathrm{C}$, and the flow rate was $0.4 \mathrm{~mL} / \mathrm{min}$ with the injection volume of $10 \mu \mathrm{L}$. The gradient flow is shown in Table 2 .

Multiple reaction monitoring (MRM) mode was used to optimize the standards and negative ionization was applied by using ESI (electrospray ionization) source. Mass transitions $(\mathrm{m} / \mathrm{z} ; \mathrm{z}=1)$ and collision energy voltages were $221.20>75.20$ and V:14 for EtG, $226.20>85$. 20 and V:18 for EtG-D5 (internal standard), $124.90>97$. 10 and V:17 for EtS, and $130.20>80.10$, V:31 for EtS-D5 (internal standard). Urine EtG and EtS levels were determined quantitatively.

Validation parameters LOD, LOQ, linearity, recovery, accuracy and imprecision of the assay were studied according to international method validation guidelines in forensic toxicology (SOFT/AAFS, SWGTOX). All parameters were calculated within the expected range for HSGC and LC-MS/MS analyses. Validation results are shown in Tables 3, 4, and 5.

\section{Statistical analysis}

Statistical analyses were performed by IBM SPSS Statistics version 24 and paired sample $\mathrm{t}$ test was used. $p$ values under 0.05 were accepted as statistically significant.

\section{Results}

Ethanol contents of the consumed beverages are given in Table 6.

There were no detectable ethanol levels in blood samples both obtained before and after consumption (at $45^{\text {th }} \mathrm{min}$.) of traditional fermented beverages.

The results of statistical analyses of EtG and EtS levels of urine initial and post-consumption $4^{\text {th }}$ hour samples

Table 2 Liqiud Choromotography (LC) gradient flow

\begin{tabular}{lll}
\hline Time & Command & Value \\
\hline $1.00 \mathrm{~min}$ & Pumb B Conc. & 95 \\
$2.00 \mathrm{~min}$ & Pumb B Conc. & 95 \\
$2.01 \mathrm{~min}$ & Pumb B Conc. & 25 \\
$1.00 \mathrm{~min}$ & Stop & - \\
\hline
\end{tabular}

Table 3 Validation results; LOD, LOQ, linearity

\begin{tabular}{llll}
\hline Analyte & LOD & LOQ & Linearity \\
\hline Ethanol & $1.34 \mathrm{mg} / \mathrm{dL}$ & $4.5 \mathrm{mg} / \mathrm{dL}$ & $0.9999(23.7-379.2 \mathrm{mg} / \mathrm{dL}) . \mathrm{r}^{2}$ \\
EtG & $3.46 \mathrm{ng} / \mathrm{mL}$ & $10.51 \mathrm{ng} / \mathrm{mL}$ & $0.9968(10-200 \mathrm{ng} / \mathrm{mL}) . \mathrm{r}^{2}$ \\
EtS & $3.67 \mathrm{ng} / \mathrm{mL}$ & $11.14 \mathrm{ng} / \mathrm{mL}$ & $0.9991(10-200 \mathrm{ng} / \mathrm{mL}) . \mathrm{r}^{2}$ \\
\hline $\begin{array}{l}\text { LOD limit of detection, LOQ limit of quantification, EtG ethyl glucuronide, EtS } \\
\text { ethyl sulphate }\end{array}$
\end{tabular}

are given in Tables 7 and 8 for all beverages. No statistically significant correlation was found between initial and postconsumption urine EtG (p: $0.726-0.705-0.183-0.172$ respectively) and EtS (p: $0.619-0.262-0.063-0.232$ respectively).

\section{Discussion}

The present study reveals ethanol concentrations of traditional fermented şalgam, kımız, boza and kefir. Ethanol concentrations were previously determined as $213 \mathrm{mg} / \mathrm{dL}$ in şalgam, $128 \mathrm{mg} / \mathrm{dL}$ in boza, and $12 \mathrm{mg} / \mathrm{dL}$ in kefir in a study by Uysal et al. (2014). Previous studies revealed that, ethanol concentrations were in a range between 79 to $503 \mathrm{mg} / \mathrm{dL}$ in şalgam samples (Tanguler and Erten 2012), 1 - 6\% in boza samples (Kose and Yucel 2003), 0.08-2\% or around $50 \mathrm{mg} / \mathrm{dL}$ in kefir samples (Irigoyen et al. 2005; Magalhães et al. 2011), and 0.6-2.5\% in kimız samples (Altay et al. 2013; Kabak and Dobson 2011). The yeasts such as Kluyveromyces, Candida, and Saccharomyces strains are responsible for converting lactose to ethanol and carbon dioxide during fermentation. Fermented beverages used in this study contain low amounts of lactic acid bacteria strains which cause formation of ethanol (Altay et al. 2013; Kabak and Dobson 2011; Magalhães et al. 2011).

To the best of our knowledge, there is no literature finding about effects of these kinds of traditional fermented beverages on blood ethanol levels and its metabolites EtG and EtS. Uysal et al. (2014) demonstrated that consumption of $200 \mathrm{~mL}$ of boza, kefir, and şalgam have not any effect on breath alcohol tests performed at 1, 3, 5, 15, and 30 min following consumption. On the other hand, in the study of Logan and Distefano (1998), positive breath alcohol results were detected when various soft drinks and certain brands of bread were kept in mouth for $20 \mathrm{~s}$. In the United States, commercially available energy drinks were investigated in Lutmer et al.'s study (Lutmer et al. 2009), in which showed certain positive results (0.006-0. $015 \mathrm{~g} / 210 \mathrm{l}$ ) on a portable breath testing device within

Table 4 Validation results; Accuracy and Imprecision of Ethanol

\begin{tabular}{|c|c|c|c|c|}
\hline \multirow[t]{2}{*}{ Analyte } & \multicolumn{2}{|c|}{$\begin{array}{l}\text { Level } 1 \\
\text { (23.7 mg/dL) }\end{array}$} & \multicolumn{2}{|c|}{$\begin{array}{l}\text { Level } 2 \\
(379.2 \text { mg/dL) }\end{array}$} \\
\hline & RSD (\%) & Bias (\%) & RSD (\%) & Bias (\%) \\
\hline Ethanol & 1.17 & 2.87 & 5.00 & 1.03 \\
\hline
\end{tabular}

$R S D$ relative standart deviation 
Table 5 Validation results; accuracy and Imprecision of EtG and EtS

\begin{tabular}{|c|c|c|c|c|c|c|}
\hline \multirow[t]{2}{*}{ Analyte } & \multicolumn{2}{|c|}{$\begin{array}{l}\text { Level } 1 \\
\text { (25 ng/mL) }\end{array}$} & \multicolumn{2}{|c|}{$\begin{array}{l}\text { Level } 2 \\
(100 \text { ng/mL) }\end{array}$} & \multicolumn{2}{|c|}{$\begin{array}{l}\text { Level } 3 \\
(250 \text { ng/mL) }\end{array}$} \\
\hline & RSD (\%) & BIAS (\%) & RSD (\%) & BIAS (\%) & RSD (\%) & BIAS (\%) \\
\hline $\mathrm{EtG}$ & 4.24 & -4.90 & 6.84 & 18.38 & 8.98 & 7.77 \\
\hline EtS & 2.40 & 3.66 & 3.91 & 1.22 & 0.44 & 5.66 \\
\hline
\end{tabular}

$R S D$ relative standart deviation, $E t G$ ethyl glucuronide, $E t S$ ethyl sulphate

$1 \mathrm{~min}$ after the consumption. However, they did not find any positive results $15 \mathrm{~min}$ after consumption. On the other hand, Musshoff et al. demonstrated that fruit juices' samples had ethanol concentrations similar to the presented study, and they have found increased EtG and EtS levels with fruit juice consumption in amounts of 1.5 to 21 (Musshoff et al. 2010). Non alcoholic beers with ethanol concentrations of 3.1 to $3.6 \mathrm{~g} / \mathrm{l}$ were investigated by Musshoff et al. (2010) and Thierauf et al. (2010) after consumption of 2 to $3 \mathrm{l}$ and $2.5 \mathrm{l}$, respectively. Both studies revealed positive urine EtG and EtS levels. Thierauf et al. (2009) also studied two different beverages with low amounts of ethanol (1 to $3 \mathrm{~g}$ ), in which urine EtG and EtS were measured $0.35-0.49 \mathrm{mg} / \mathrm{l}$ and $0.26 \mathrm{mg} / \mathrm{l}$ after $1 \mathrm{~g}$ consumption and $1.36 \mathrm{mg} / \mathrm{l}$ and $0.86 \mathrm{mg} / \mathrm{l}$ after $3 \mathrm{~g}$ consumption, respectively. Prominently, these values were over the cut-off levels accepted in the United States which are ranging between 0.10 and $1 \mathrm{mg} / \mathrm{l}$.

The studies by Logan and Distefano (1998), and Lutmer et al. (2009) dealt with foodstuffs or beverages containing similar ethanol concentrations with the traditional fermented beverages used in our study. They demonstrated that it is possible to obtain positive breath alcohol test results within a short time interval after consumption, although blood alcohol levels were negative. It is suggested that, breath alcohol test should be performed at least after a $15 \mathrm{~min}$ waiting period, following alleged time of consumption, in order to eliminate false positive results. Otherwise portable breath test devices may cause suspicious results and claiming of false positivity at roadside tests. In Turkey, traditional fermented beverages are often being exploited as an excuse for a positive breath alcohol test, even if tested person's blood alcohol is truly positive for alcohol. Our present study showed that consumption of $300 \mathrm{ml}$ traditional fermented beverage has no effects on blood alcohol and urine EtG and EtS levels. Additionally, Center for Abuse Treatment has suggested that effects of

Table 6 Ethanol contents of beverages

\begin{tabular}{ll}
\hline Beverage & Ethanol \\
\hline Şalgam & $80.02 \mathrm{mg} / \mathrm{dl}$ \\
Kefir & $6.07 \mathrm{mg} / \mathrm{dl}$ \\
Boza & $30.02 \mathrm{mg} / \mathrm{dl}$ \\
Kımız & $57.83 \mathrm{mg} / \mathrm{dl}$ \\
\hline
\end{tabular}

Table 7 Statistical results of EtG levels $(\mathrm{ng} / \mathrm{ml})$ of urine samples

\begin{tabular}{lll}
\hline & Mean \pm Std. Deviation & $P$ \\
\hline Kımız EtG 0 Hour & $34.94 \pm 18.45$ & .183 \\
Kımız EtG 4 Hour & $30.52 \pm 14.51$ & \\
Şalgam EtG 0 Hour & $38.13 \pm 17.69$ & .726 \\
Şalgam EtG 4 Hour & $39.15 \pm 13.57$ & \\
Boza EtG 0 Hour & $36.73 \pm 12.73$ & .705 \\
Boza EtG 4 Hour & $34.79 \pm 11.88$ & \\
Kefir EtG 0 Hour & $29.06 \pm 10.81$ & .172 \\
Kefir EtG 4 Hour & $27.11 \pm 9.21$ & \\
\hline
\end{tabular}

$E t G$ ethyl glucuronide, EtS ethyl sulphate

foods, beverages, hygiene products, cosmetics, etc. on blood ethanol and other biomarkers, which may contain alcohol and can cause false positive results, must be researched (Thierauf et al. 2009).

Limitations of our study are small number of sample size, consumption of low amount of beverage, and utilization of fresh fermented beverages. Although our results are applied for $300 \mathrm{~mL}$ consumption, higher consumption levels could change blood alcohol and urine EtG and EtS concentration. Lutmer et al. (Lutmer et al. 2009) indicated that in order to obtain $20 \mathrm{mg} / \mathrm{dL}$ blood ethanol level, about 5-6 L energy drink, with similar ethanol concentration to fermented beverages, should be consumed. On the other hand, fermentation is an ongoing process that causes more ethanol formation especially if the process or/and storage time gets prolonged. We used fresh traditional fermented beverages in the presented study; however, it is possible that homemade or awaited beverages could have distinct ethanol concentrations which are likely to affect the blood alcohol results.

\section{Conclusion}

At the present study, it is demonstrated that consumption of $300 \mathrm{~mL}$ of traditional fermented beverages, Şalgam, Boza, Kımız, and Kefir did not affect blood alcohol levels. Furthermore, this consumption does not cause any effect on concentrations of ethanol metabolites in urine. Our

Table 8 Statistical results of EtS levels $(\mathrm{ng} / \mathrm{ml})$ of urine samples

\begin{tabular}{lll}
\hline & Mean \pm Std. Deviation & $\mathrm{P}$ \\
\hline Kımız EtS 0 Hour & $11.64 \pm 18.62$ & .063 \\
Kımız EtS 4 Hour & $7.51 \pm 11.16$ & \\
Şalgam EtS 0 Hour & $9.11 \pm 10.91$ & .619 \\
Şalgam EtS 4 Hour & $7.88 \pm 3.66$ & .262 \\
Boza EtS 0 Hour & $10.28 \pm 11.63$ & \\
Boza EtS 4 Hour & $7.60 \pm 5.83$ & .232 \\
Kefir EtS 0 Hour & $12.5 \pm 3.6$ & \\
Kefir EtS 4 Hour & $11.4 \pm 3.4$ & \\
\hline
\end{tabular}

$E t G$ ethyl glucuronide, EtS ethyl sulphate 
findings suggest that blood ethanol and urine ethanol metabolites should be analyzed in order to eliminate false positive results, in alleged false positive cases. However, further studies are needed with larger sample sizes and with different amounts of consumption of fermented beverages.

\section{Abbreviations}

AAFS: American Academy of Forensic Sciences; ESI: Electrospray ionization; EtG: Ethyl-glucuronide; EtS: Ethyl-sulphate; FID: Flame ionization detector;

GC: Gas chromatograph; HS - GC: Headspace gas chromatograph; IS: Internal standards; LC: Liquid chromatography; LC-MS/MS: Liquid chromatography Tandem mass spectrometry; LOD: Limit of detection; LOQ: Limit of Quantification; MRM: Multiple reaction monitoring; MS: Mass spectrometry; RSD: Relative standard deviation; SOFT: Society of Forensic Toxicologists; SWGTOX: Scientific Working Group for Forensic Toxicology

\section{Acknowledgements}

I attest to the fact that all authors listed on the title page have read the manuscript, attest to the validity and legitimacy of the data and its interpretation, and agree to its submission to "Egyptian Journal of Forensic Sciences"

\section{Funding}

The manuscript were funded by Hacettepe University, award number THD-2015-6117.

\section{Availability of data and materials}

All author agree that materials described in the manuscript, including all relevant raw data, will be freely available to any scientist wishing to use them for non-commercial purposes.

\section{Authors' contributions}

All persons listed as authors have contributed to preparing the manuscript and no person or persons other than the authors listed have contributed significantly to its preparation. All authors read and approved the final manuscript.

\section{Authors' information}

All authors' information contributed the manuscript were listed in first page.

\section{Ethics approval and consent to participate}

The experimental procedure was approved by the Hacettepe University Ethical Committee in Turkey and all the volunteers gave informed consent.

\section{Consent for publication}

All author agree to manuscript entitled "The Effects of Traditional Fermented Beverages on Ethanol, Ethyl Glucuronide and Ethyl Sulphate Levels" submission to "Egyptian Journal of Forensic Sciences".

\section{Competing interests}

The authors declare that they have no competing interests.

\section{Publisher's Note}

Springer Nature remains neutral with regard to jurisdictional claims in published maps and institutional affiliations.

\section{Author details}

${ }^{1}$ Department of Forensic Medicine, Hacettepe University Medical Faculty, 06100 Ankara, Turkey. ${ }^{2}$ Department of Medical Biochemistry, Hacettepe University Medical Faculty, Ankara, Turkey.

Received: 1 November 2017 Accepted: 18 April 2018

Published online: 25 April 2018

\section{References}

Altay F, Karbancioglu-Güler F, Daskaya-Dikmen C, Heperkan D (2013) A review on traditional Turkish fermented non-alcoholic beverages: microbiota, fermentation process and quality characteristics. Int J Food Microbiol 167:44-56
Helander A, Beck O (2004) Mass spectrometric identification of ethyl sulfate as an ethanol metabolite in humans. Clin Chem 50:936-937

Irigoyen A, Arana I, Castiella M, Torre P, Ibanez F (2005) Microbiological, physicochemical, and sensory characteristics of kefir during storage. Food Chem 90:613-620

Kabak B, Dobson AD (2011) An introduction to the traditional fermented foods and beverages of Turkey. Crit Rev Food Sci Nutr 51:248-260

Kose E, Yucel U (2003) Chemical composition of boza. J Food Technol 1:191-193

Logan BK, Distefano S (1998) Ethanol content of various foods and soft drinks and their potential for interference with a breath-alcohol test. J Anal Toxicol 22:181-183

Lutmer B, Zurfluh C, Long C (2009) Potential effect of alcohol content in energy drinks on breath alcohol testing. J Anal Toxicol 33:167-169

Magalhães KT, Pereira GVM, Campos CR, Dragone G, Schwan RF (2011) Brazilian kefir: structure, microbial communities and chemical composition. Braz J Microbiol 42:693-702

Musshoff F, Albermann E, Madea B (2010) Ethyl glucuronide and ethyl sulfate in urine after consumption of various beverages and foods - misleading results? Int J Legal Med 124:623-630

Rati Rao E, Vijayendra S, Varadaraj M (2006) Fermentation biotechnology of traditional foods of the Indian subcontinent. In Food Biotechnology 2nd ed. (ed. by K. Shetty, G. Paliyath, A. Pometto and R. E. Levin). Boca Raton: CRC Press

SAMHSA - Substance Abuse and Mental Health Services Administration (2012) The role of biomarkers in the treatment of alcohol use disorders, 2012 revision. Advisory 11:1-8

Tamang JP, Kailasapathy K (2010) Fermented foods and beverages of the world. Boca Raton: CRC Press

Tanguler H, Erten H (2012) Chemical and microbiological characteristics of shalgam (şalgam): a traditional turkish lactic acid fermented beverage. J Food Qual 35:298-306

Thierauf A, Gnann H, Wohlfarth A, Auwärter V, Perdekamp MG, Buttler K-J, Wurst FM, Weinmann W (2010) Urine tested positive for ethyl glucuronide and ethyl sulphate after the consumption of "non-alcoholic" beer. Forensic Sci Int 202:82-85

Thierauf A, Halter CC, Rana S, Auwaerter V, Wohlfarth A, Wurst FM, Weinmann W (2009) Urine tested positive for ethyl glucuronide after trace amounts of ethanol. Addiction 104:2007-2012

Uysal C, Karapirli M, Inanici MA (2014) Effects of some of the regional Turkish fermented foods and medications on respiratory alcohol levels. Turk J Med Sci 44:720-727

Walsham NE, Sherwood RA (2014) Ethyl glucuronide and ethyl sulfate. Adv Clin Chem 67:47-71

Wurst FM, Kempter C, Metzger J, Seidl S, Alt A (2000) Ethyl glucuronide: a marker of recent alcohol consumption with clinical and forensic implications. Alcohol 20:111-116

\section{Submit your manuscript to a SpringerOpen ${ }^{\circ}$ journal and benefit from:}

- Convenient online submission

Rigorous peer review

- Open access: articles freely available online

- High visibility within the field

- Retaining the copyright to your article

Submit your next manuscript at $>$ springeropen.com 